\title{
Courtship and the Hill of Truth: Religion, Career, and the Purification of Motives in Donne's Satyres and Sermons
}

BRENT L. NELSON

Resume : Cet article se propose d'examiner comment Donne, dans sa "Satyre III », manipule l'amour pour l'Être divin par l'intermédiaire de la " hill of Truth ». L'article tente aussi de démontrer en quoi cette image constitue le centre symbolique des satires de l'auteur et une solution au problème du dévouement sociopolitique décrit dans les quatre poèmes. La fonction rhétorique de l'ascension saute aux yeux dans les sermons, où Donne attise avec méthode le désir et l'ambition pour diriger les auditeurs vers l'amour de l'Être divin.

$\mathrm{D}$ onne wrote his Satyres as an ambitious young man in search of a public career worthy of his talents, and he wrote these poems for other ambitious young men seeking the same. ${ }^{1}$ These are practical poems that seek to answer a common but essential problem: how does one engage actively in the world of affairs without becoming polluted and compromised by it? This situation, the need to balance conscience with socio-political concerns, naturally evokes a casuistical mindset, but the means Donne chooses are poetic rather than theological. ${ }^{2}$ When critics talk about the poetic operation of the Satyres as a whole, it is often in terms of a narrative progression from a young scholar cloistered in his study to the mature Donne taking up a position as Sir Thomas Egerton's secretary. ${ }^{3}$ The narrative, however, offers no lasting solution to the problem of pollution: it culminates with Donne finding a position within the world of affairs, serving Egerton and the Queen in the task of weeding out corruption in the courts, but even this new career is no guarantee against personal pollution. ${ }^{4}$

Moreover, the narrative unity of this set of poems, such as it is, is disrupted by the conspicuous insertion of the third poem, a meditative rather than narrative poem, whose mode is private rather than public. ${ }^{5}$ Yet, 
as the new Variorum edition of Donne's Satyres will make clear, by around the turn of the sixteenth century the five poems that we generally call the "satires" were completed and circulating as a set in the same order that they are printed in today. ${ }^{6}$ This would suggest that the placement of Satyre III is by design: I propose that it was designed as a symbolic solution to the problem of career and the threat of moral pollution in situations where individual conscience comes into conflict with social demands and political exigencies, a concern that Donne similarly addresses again some years later in the sermons. Thomas V. Moore argues that the purpose of this central poem is to describe the state of mind that is necessary if the search for career is to have any success; however, beyond mere description, there is a rhetorical, symbolic function in this poem's meditation. ${ }^{7}$ Richard C. Newton builds on F. R. Leavis's observation that the Satyres "seem to do what they say," adding that they "force upon the reader a mental reenactment of the search which in this Satyre, and indeed throughout his verse, Donne requires." ${ }^{8}$ More specifically, Satyre III aims to involve its audience in a symbolic reorientation of the motives dramatized in the surrounding narrative. This reorientation is the symbolic action (to borrow a phrase from Kenneth Burke) of the poem, a kind of casuistry that is, as Camille Slights suggests, "conducted with the same imperfect mental processes that people use in their amatory and domestic lives"; 9 more specifically, Donne employs a baptized mode of courtship that turns the logic of worldly pursuits of desire toward a pursuit of a higher end. In the Satyres Donne employs a rhetoric of courtship that is echoed and developed into a rich resource for addressing similar concerns of career and devotion in the sermons.

The chief concern of Donne's satyric persona in Satyre $I$ is that ambition and activity in the world of affairs are incompatible with conscience and moral constancy. Here the active life is characterized by inconstancy, moral pollution, and baseness. Yet the speaker also knows that it is his moral duty to employ his abilities for the public good. In the rest of the Satyres Donne, an ambitious young man in his early twenties, uses his satiric persona to scrutinize the vocations by which he may enter into public life: law, poetry, politics, and even state religion. Each of these avenues of public life is inclined toward corruption and is characterized by decay and pollution. This pollution and the need for purification are represented in themes of moral corruption and inconstancy, both of which scholars have identified with a dominant imagery pattern of clothing. 10 Pollution is also prominently figured as disease and poor digestion. In the sermons, good digestion is an image of spiritual purification and wholesomeness. ${ }^{11}$ Obversely, in the Satyres, disease, decay, and poor digestion 
signify moral pollution. The lawyer Coscus is associated with an outbreak of pustules that progress to a full-blown disease, probably venereal (II.41-42). The courtier of the fourth poem offers "home-meats" (gossip) to the speaker, whose response is to "belch, spue, spit, / Looke pale, and sickly," a natural reflex of the body to purge itself of pollution (IV.109-10). In another application of the metaphor, in the final Satyre, public officers are "the devouring stomacke, and Suiters / The excrements, which they voyd" (18-19); however, Donne's solution to the problem of pollution is ultimately not purgation, but rather assimilation — a good digestion that takes what is potentially good and makes it good by applying it to good uses. In Satyre II, the speaker describes the hack poet-plagiarist who

... doth chaw

Others wits fruits, and in his ravenous maw

Rankly digested, doth those things out-spue,

As his owne things ... (25-28)

In contradistinction to the normal, wholesome process of digestion, this material is digested "rankly," which is glossed by John Shawcross as "inadequately" but also suggests filthiness, so that the result is vile vomit. Donne then reapplies the metaphor, imagining that some of this material is retained and digested, in which case the digestive process extracts and, ideally, assimilates all that is good (the original poet's material) and leaves behind only the extracted pollution (excrement) of the hack (27-30). In this case, the nutritious material is lost and good to no one, not even the plagiarist. The positive application of assimilation is to be found in another image, the hill of Satyre III.

This imagery of pollution complements a concentration of motives and strategies of courtship in the Satyres. The first poem quickly establishes the central concern of the Satyres as a whole: the problem of courtship cast in terms of the traditional tension between the demands of the active life and the contemplative life. ${ }^{12}$ The courtship theme continues in Satyre II, where Ronald J. Corthell finds Donne employing tropes of courtship common in the courtesy literature of the period, which supplied the single richest source for ideas of self-fashioning and a site for an ambivalent struggle with ideology. ${ }^{13}$ Similarly, Nancy Mason Bradbury characterizes the fourth poem as a decorous response to contemporary anxieties about court and courtiers; Dennis Flynn describes the courtship milieu of the fifth, where Donne carefully finesses his new position as secretary to Sir Thomas Egerton and, by extension, as servant to the Queen, both of whom were implicitly tainted by Donne's detailed elaboration of political corruption. ${ }^{14}$ Donne's chief concern throughout the Satyres, how- 
ever, is not for his betters but for young men like himself. The key question in his mind arises naturally from the circumstances of the very first Satyre: who can make courtiers good? (V.4).

Courtship, it seems - the grasping at positions of power-is part of the problem; but courtship - a baptized version of courtship - also, ironically, provides the answer to the problem posed by the Satyres, that of maintaining personal purity in the world of public affairs. This solution is found in the symbolic centre of these five poems, the hill of truth in Satyre $I I I$, which enacts a mode of thought that derives directly from the culture of courtship. While Satyre V brings the narrative of the set to a close, the third Satyre brings the group to a symbolic solution. Ronald Corthell identifies the symbolic quality of this Satyre, with reference to two critics:

As a piece of poetic courtship, the satire might best be seen as what Frederic Jameson has called a socially symbolic act: 'the imaginary resolution of the objective contradictions,' irreconcilable in social reality, 'to which it thus constitutes an active response'. As a symbolic act [alluding now to Kenneth Burke], the poem is marked by equivocation; it is 'at one and the same time the accomplishment of an act and the latter's substitute, a way of acting on the world and of compensating for the impossibility of such action all at once'. ${ }^{15}$

Corthell stops short of using Burke to explain how this symbol works. In this essay I use Burke's theories of courtship to elaborate the rhetorical and symbolic function of the central image of the Satyres, the hill of truth. I then show how Donne's mature handling of some of these same modes of thought in the sermons helps to clarify the rhetorical function of this figure in resolving the problems of career that Donne addressed as a young man and continued to address as a preacher in the most popular pulpit in England. In short, this central poem and its central image- the hill of truth-serve a symbolic function with respect to the rest of the Satyres and the problem they elaborate. The image enacts a ritual of purification, enabling the satirist and the audience whom he counsels to continue seeking a public career in precarious circumstances by subordinating this pursuit to the larger project of seeking truth. Career is made to be an element in a larger courtship that envisions as its end truth in religion and, ultimately, God.

Most scholars who write about Donne's hill imagery direct their attention to the vehicle of the metaphor in an attempt to relate it to possible sources. This effort is misdirected. Even the Dort medal cited by Paul Sellin cannot serve as a single source for Donne's image. There are a number of details that don't correspond, and those that do are commonplace in the 
period. ${ }^{16}$ The more crucial issue is the tenor of the metaphor, the kind of meaning that was attached to these commonplaces. M. Thomas Hester identifies one of these strains of meaning: the dialectical mode signified by the winding route of ascent up the hill. ${ }^{17}$ But there are other commonplace ideas associated with this image. The top of a hill typically signified a place of privilege that is achieved only by incremental labour, such as patronage or sexual courtship as commonly figured in the Petrarchan tradition or in Romance. The frontispiece to Lady Mary Wroth's Urania (1621), for example, depicts a scene early in the romance where the questing party arrives at a hill crowned with a stately palace, the House of Love (fig. 1). The hill represents the goad of desire: amorous, political, or even spiritual. It also signifies a Platonic/mystical process of ascent toward an ideal. ${ }^{18}$ This ascent typically carried associations of purification, as illustrated in St. John of the Cross's "Mount of Perfection" (fig. 2). Along the bottom of the mount and along the side-roads are the desires and pleasures of the world: these are the paths of the imperfect and wayward spirit; but the central way moves directly upward, past the attractions of the world, through the lower, then to the higher virtues, and finally to the apex of eternal blessedness in plenitude of grace and the perpetual banquet of union with God. Dennis Flynn's emerging picture of Donne's Roman Catholic upbringing, and especially his connections to the continent, suggests that Donne would very likely have been exposed to the teachings of St. John of the Cross $;{ }^{19}$ but rather than attempt to prove a specific source, I am trying to establish a commonplace of desire and purification signified by imagery of ascent. The mystics were but one group of contributors to this commonplace.

Harry J. Brown argues that much that is understood to be "metaphysical" in Donne's poetry can be traced to ideas in the Spanish mystics. Specifically, he identifies four key ideas: 1) interiorization of religious experience; 2) eroticization of that experience culminating in 3) a heightened physical and spiritual state of "ecstasy" [a momentary encounter]; and 4) the idea of mystical marriage of the soul to God in a lasting relationship. ${ }^{20}$ In Brown's formulation there is a faint and perhaps surprising hint of kinship between mysticism and the romance of Mary Wroth. Ignatius, Brown notes, was a great lover of romances, which informs his eroticization of the divine and his "emphasis on the quest of the individual soul, like a knight errant beset by peril on all sides." 21 Although Ignatius is his focus here, Brown finds a similar eroticization at work in both Teresa of Avila and St. John of the Cross (see his Canticles and poems for examples). The courtship significance is striking and bears obvious correlation to Donne's third Satyre, where a transcendent object of desire is both eroti- 


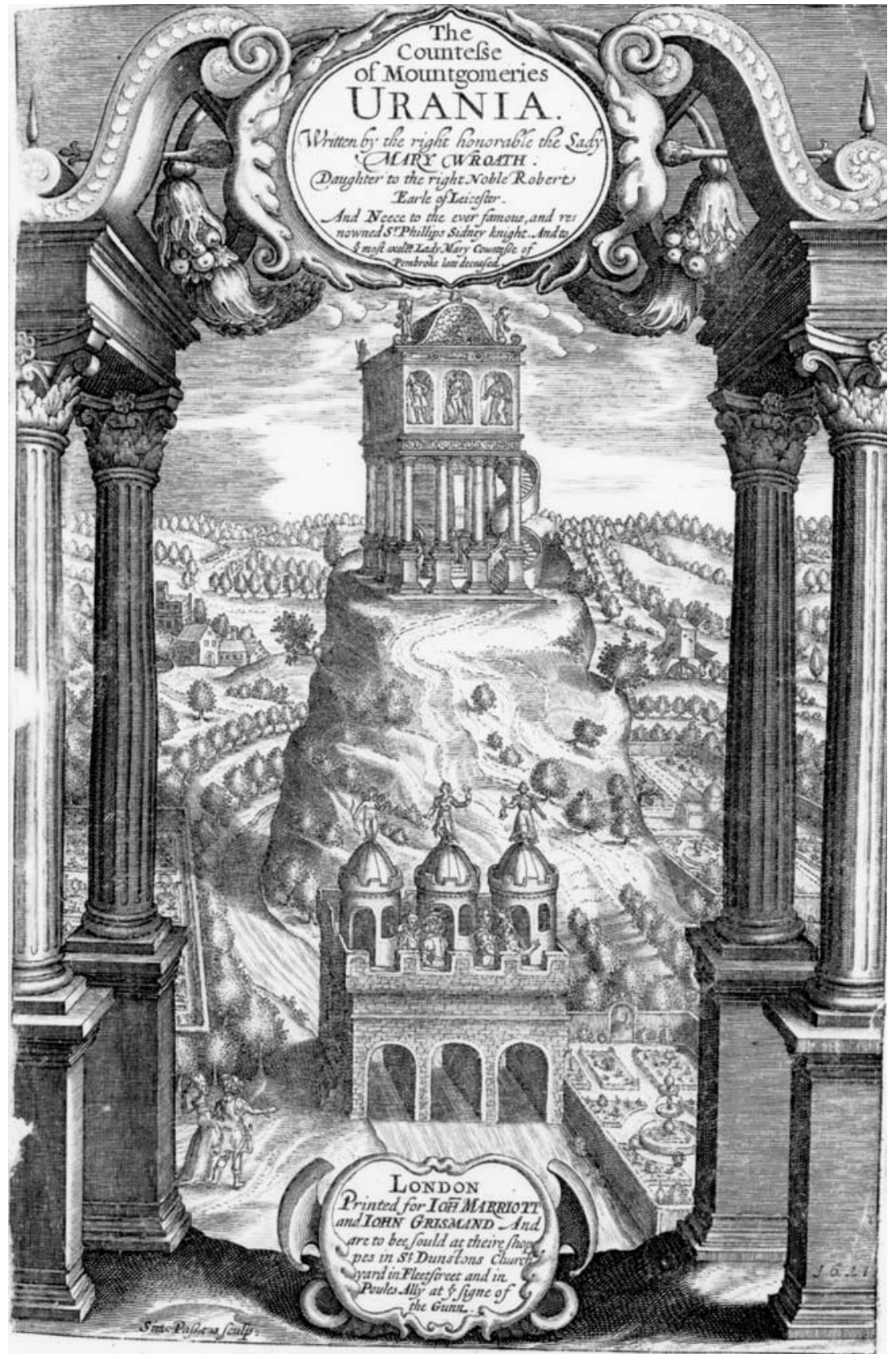

Fig. 1. Frontispiece to Mary Wroth, The Countesse of Mountgomeries Urania (London, 1621). Reproduced by permission of The Huntington Library, San Marino, California. 


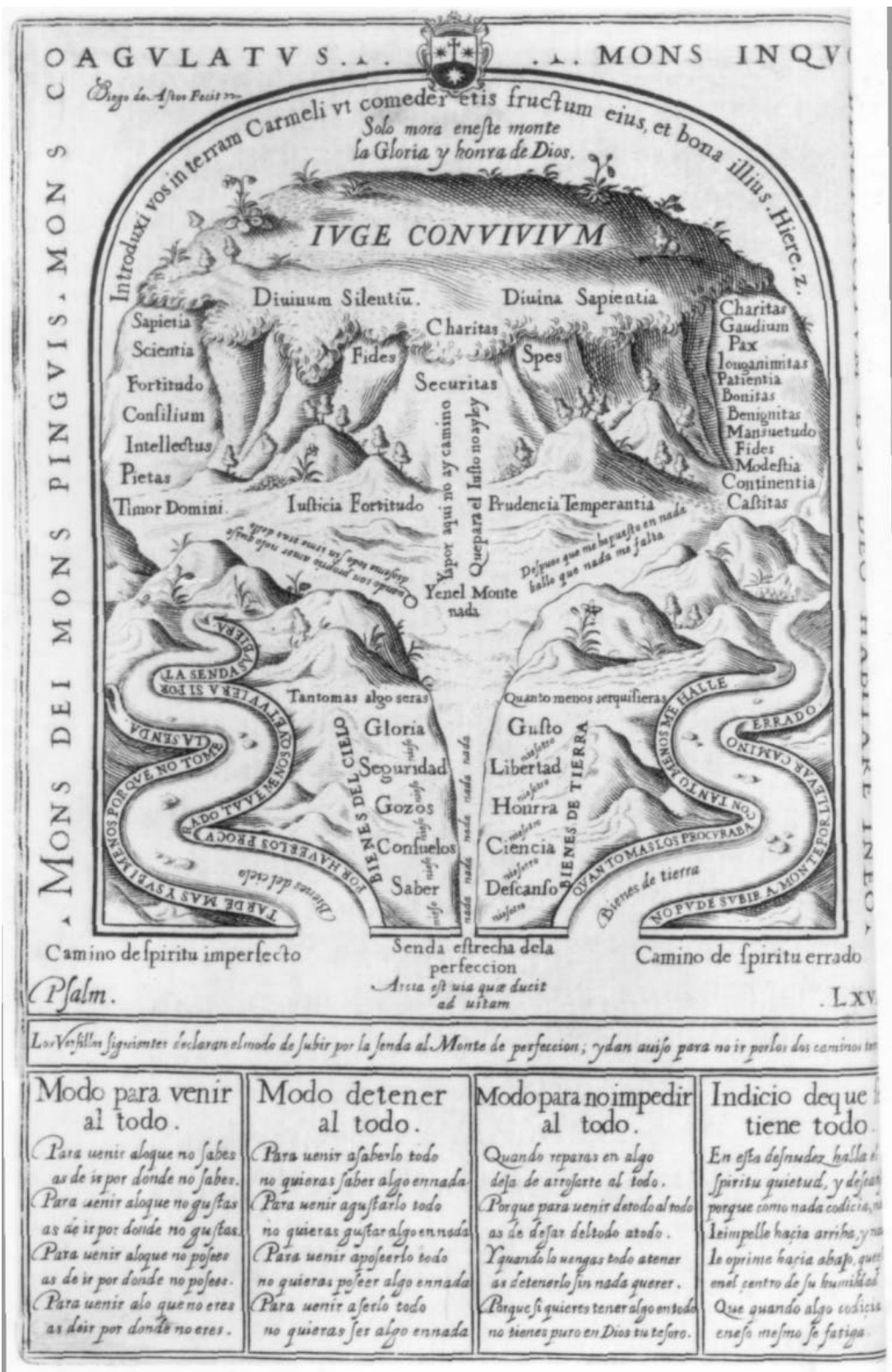

Fig. 2. From John of the Cross, Obras espirituales (Barcelona, 1619), p. 34. Reproduced by permission of The British Library. 
cized and spiritualized and the questing subject pursues this object amidst great peril. Another of the mystical topoi, mystical marriage, is also evoked here, although the object of desire is not a bride but a mistress (I will remark on this important difference later). For the Neoplatonists writing in the mystical tradition, this idea of eroticization of religious ecstasy, explains Bernard McGinn, "motivates the contemplative life leading to the vision of God." 22 This eroticization functions rhetorically, goading the subject in the way of purification. Donne's image includes a similar notion of ascent through worldly desires toward the greater, purer good, although the way to this end that it symbolizes-outright rejection and purgation of earthly desires and means-is one Donne rejects.

According to Burke any ascent through hierarchy is a variant of courtship representing a kind of purification with respect to the apex of that hierarchy, the object of desire, whatever it may be: God, king, or even an idea, such as honour. Each person finds his or her place in a hierarchy according to his or her relative proximity to its apex. Accordingly, motives of courtship arise amid conditions of estrangement, a perceived distance between the subject and the object of desire. First of all, then, for the purposes of my analysis, hierarchy implies estrangement which in turn induces a desire to ascend in a given hierarchy. Secondly, this ascent implies purification. This is perhaps most evident in the Renaissance notion of the Great Chain of Being, which extends from the lowest creatures of the mineral and vegetable classes through the sensitive on up through the grades of spiritual beings culminating in God, the perfect, pure, and holy. Here each creature finds its rank according to its degree of similarity to God. By analogy, the apex of any hierarchy, its ultimate term (as Burke calls it), becomes the governing principle, the chief value that determines the relative value and order (or purity) of each being or element in the hierarchy. This ultimate term is the most pure position in the hierarchy, and thus the supreme object of desire, or the greatest good. Correspondingly, the base of the hierarchy is characterized by pollution, variability, and distance from the good. Thus to move up the social order is to increase in purity with respect to the pinnacle of the social hierarchy; to be at the bottom is to be base, morally or socially. ${ }^{23}$

The dialectical quality identified by Hester in the hill image of Satyre III functions along the lines of a courtship through hierarchy. The dialectical, reorienting function of courtship is illustrated in Castiglione's Book of the Courtier, a seminal text both for Donne's culture and for Burke's ideas on hierarchy. ${ }^{24}$ In Books I to III the courtiers' discussion moves comfortably between courtships that are social (between fellow courtiers and between courtier and sovereign) and those that are sexual, and the 
appropriate strategies for advancing in each. They appear to be analogous in every respect. This discussion then takes an important turn in Book IV, where Cardinal Bembo draws political and erotic motives toward the ultimate end of courting the divine. Desire of physical beauty is not eschewed; rather it is seen as the goad that stirs the subject in the way of courtship. And if properly directed, this desire can lead to a higher, spiritual desire for pure beauty in God. Thus a desire that, when misdirected, becomes a moral fault may, when properly directed, become a virtue that leads by similitude toward a higher virtue. Conceived according to this Platonic scheme, courtship can be broadened to include any order that is dialectically organized in relation to an ultimate object of desire.

Donne's hill imagery resonates with courtship motives, beginning in line 5 with a reference to "Mistresse faire Religion" who is "worthy' of all our Soules devotion." 25 Significantly, she is a mistress, an object of pure desire that is elusive in a way that a wife is not. Donne's image seeks not only to induce a dialectical mode of thought, but also to stir up passion and foster a desire to engage in this dialectical pursuit. What follows in lines 7-32 is an admonition to those who are courting temporal glory and achievement (honour, valour, discovery) elsewhere. The satirist then scrutinizes a series of religious devotees (Mirreus, Crants, Graius, Phrygius, and Graccus) whom he describes as lovers, each pursing the beloved Church of his choice, and each for reasons or motives of his own. And then, at the centre of the poem is truth personified as the feminine-beloved who must be courted. The speaker urges the reader to "be busie to seeke her" and, at the same time, to

... doubt wisely, in strange way

To stand inquiring right, is not to stray;

To sleepe, or runne wrong, is: on a huge hill,

Cragged, and steep, Truth stands, and hee that will

Reach her, about must, and about must goe;

And what the' hills suddennes resists, winne so. $(74,77-82)$

This hill image serves to counter the misguided, self-centred motives of Mirreus, Crants, and the rest. Donne says, "To'adore, or scorne an image, or protest, / May all be bad" (76-77, emphasis added). The motives with which these activities are pursued become purified when they are undertaken in a rigorous dialectic of doubting wisely and seeking truth, drawing all pursuits toward the ultimate end of truth. Similarly, this hill induces a reorientation of the problem of career in the Satyres as a whole. Coscus in the fourth Satyre, for example, is also compromised by temporal motives that serve as ends in themselves. The image poses a solution to Coscus's 
moral pollution by envisioning an end beyond mere gain, an end that is achieved in a continuing dialectic or courtship of purer motives in pursuit of the transcendent: truth, God, or religion.

This interpretation of Donne's hill image according to Burke's model of courtship is confirmed by Donne's use of similar imagery in the sermons. Donne concludes his fourth and most savage Satyre by comparing his work of satire with that of the sermon:

... Preachers which are

Seas of Wits and Arts, you can, then dare,

Drowne the sinnes of this place, for, for mee

Which am but a scarce brooke, it enough shall bee

To wash the staines away ... (237-41)

Donne's slightly mocking and ironic characterization of preachers in line 238 does not negate the respect he pays to the pulpit, and notwithstanding Donne's Maccabean modesty (line 242), the stream of the satirist shares many generic features with the ocean of the preacher. Above all, both aim at social reform by confronting vice. ${ }^{26}$ Donne himself hints at generic connections: in his comments on the prophet Jeremiah, a "bitter, and satyricall preacher," Donne implicitly describes part of his own satiric method (which, numerous critics point out, borrows from Jeremiah) as self-implicating in anatomizing his own sin and guiltiness (not that of his congregations), and bitter, such that he becomes "a burthen to every tender conscience" (2:1.130-49). ${ }^{27}$ Modern scholars have also noted the kinship between these two modes of discourse. ${ }^{28}$ Was Donne already looking forward to a more adequate public voice for this purpose? There is a kind of symmetry in Donne's career in letters, beginning with satires and ending with sermons. No doubt Donne changed a good deal as a man, from the brash young poet to the venerable preacher of St. Paul's, yet there is continuity in the thought and rhetoric of both voices. In Satyre IV, the satirist's method is that of a traditional preacher, somewhat akin to Jeremiah, who deals with sinful desire by effacing it; but in the Satyres as a group, there is another method for dealing with carnal desire, one which informs the mature Donne as well in his sermons.

Career is a favorite topic of Donne the preacher, and in the sermons Donne's handling of career helps clarify the similar operation of the Satyres. In the sermons, Donne also employs hierarchical imagery of ascent to incite a motivating desire and effect a purification of conscience through diligent, dialectical deliberation; and here again we find a coincidence of deliberation about personal alignment with public religious positions and pursuit of personal career in the public realm. This concern of career is 
addressed in a sermon possibly preached at Lincoln's Inn, to an audience of young, ambitious men anxious for worldly advancement, where Donne frames his discussion of preaching in the larger context of career and public service. He opens by telling his audience,

This is the true reason why men are Ennobled, why men are raised, why men are inriched, that they might glorifie God the more, by that eminency; This is truly to be a good Student, Scrutari Scripturas, To search the Scriptures, in which is eternall life: This is truly to be called to the Barre, to be Crucified with Christ Jesus: And to be called to the Bench, to have part in his Resurrection, and raigne in glory with him: and to be a Judge, to judge thy selfe, that thou beest not judged to condemnation, by Christ Jesus: Offices and Titles, and Dignities, make thee, in the eye, and tongue of the world, a better man; be truly a better man, between God and thee, for them, and they were well placed. (5:1.7-17)

Later, in the first partition of the sermon, Donne cites the example of St. Peter and his careful deliberation before deciding to expand his preaching ministry from the Jews toward the Gentiles, the story from which his text, Acts 10:44, is taken. It may not be coincidental that Donne too wrestled with the idea of a career just as he was contending with his own religious beliefs and associations. Like Peter, this personal deliberation is a step in opening up the way to a public preaching ministry. "This very scruple," says Donne, "was the voyce and question of God in him: to come to a doubt, and to a debatement in any religious duty, is the voyce of God in our conscience: Would you know the truth? Doubt, and then you will inquire" (104-7). Donne goes on to note that God immediately resolves Peter's doubt and tells him that those things he feared were unclean, the Gentiles and their Gentile ways, were in fact made clean by God's calling of him: "He lets downe a sheet from heaven with all kinde of beasts and fowles, and tels him, that Nothing is uncleane" (115-16). Peter's conscience was resolved when he took the attitude of Christ; "as his Master had said, Cibus meus est, My meat is to doe my Fathers will that sent me" (124-25). A right orientation in courtship purifies worldly involvement.

To illustrate how this hill of purification functions rhetorically, I would like to draw attention to a sermon Donne preached relatively early in his ministry. ${ }^{29}$ Though this sermon was composed and delivered some 16 or so years after Donne completed the Satyres, it shares the same frame of reference as Donne's earlier work. At this early point in his career in the church, Donne would have remembered very well the circumstances of his own search for career. ${ }^{30}$ Here, in a context that again raises the problem of balancing public and private concerns, Donne makes the purification significance of ascent clear. In this his first St. Paul's Cross sermon, on 24 
March 1616/7, Donne preaches on the subject of purity to an audience comprised of a large cross-section of Londoners, many of them courtiers, lawyers, and politicians. The sermon's header tells us his audience included "the Lords of the Council, and other Honorable Persons" and that it was preached on the anniversary of the king's coronation, although the king himself was abroad in Scotland. ${ }^{31}$ For this occasion Donne aptly chose as his text Proverbs 22:11: "He that loveth pureness of heart, for the grace of his lips, the king shall be his friend." Throughout the sermon Donne directly addresses the subject-king relationship, emphasizing the mutual duties and responsibilities of each; but upon this situation charged with motives of courtship and worldly advancement, Donne superimposes another hierarchy which transcends all motives of politics and ambition. The sermon's text promises a means of winning the king's favour, but at the same time Donne calls his congregants' attention to a more severe estrangement, a more grave matter of courtship for the yet-impure of heart, namely "Privation of the presence of God"- - a point that would have been punctuated by the absence the king, God's representative on earth (1:3.114-15).

M. L. Donnelly discusses this sermon in terms of divine analogy, arguing that Donne uses the Protestant discourse of calling to rationalize ambition and "to quiet his anxiety of pride and conscience." 32 Donnelly finds first in Donne's poetry and then in his sermon on Proverbs 22:11 a habit of "lay[ing] hold of the patterns of worldly success in his culture by casting his reflections on politics and society into theological language" and using "tropes taken from divinity as a way of translating, representing, or realizing the meaning of [worldly] experience." 33 In this mode Donne uses divine analogies to represent the intensity of his personal desire and anxiety, to flatter patrons, or to present a convincing representation of the ways of the world. Donne is seen at times to be putting a sanctified appearance on worldly motives, and at others to be balancing worldly ambitions for advancement with heavenly concerns for the state of his soul. ${ }^{34}$ But Donne's mode of courtship, expressed in the divine analogy (specifically the operations of grace), is more than an intellectual trick of self-justification, a redeeming of appearances, or a "powerful homologue explaining the workings of his social and political world": 35 it is an earnest re-imagining, a transformation of the very nature of one's involvement in the world.

In this sermon, as in the Satyres, Donne once again seeks to reconcile a desire for worldly involvement and advancement with the imperative of purity. Donne's underlying assumption in this sermon is similar to that of the Satyres. Purity of conscience (pure lips) is essential and so is involvement in a public vocation, which is Donne's interpretation of the phrase, 
"grace of one's lips." Elaborating this portion of his text, Donne says, "this Grace of lips, in some proportion, in some measure, every man is bound in conscience to procure to himself; he is bound to enable himself to be useful and profitable to the Publick, in some course, in some vocation" (887-90). He goes so far as to make worldly ambition a spiritual necessity, saying "he that will be nothing in this world, shall be nothing in the next" (947-48). Far from being eschewed, ambition should be encouraged. Throughout the sermon Donne evokes this worldly desire in order to extend it toward spiritual pursuits.

The question, then, is how does one enter into this life of ambition and social involvement without becoming tainted by it? The solution in this sermon, one which occupies most of the sermon and almost all of the first partition, is a proper revaluation of worldly pursuits (grace of the lips) in light of a controlling principle, a love of purity. One must have abilities, says Donne, "but he must not be in love with them, nor over-value them" (40-41). It is the love of purity that prevents this from happening. Moreover, this orientation has a transforming effect. Love, says Donne early in the sermon, "is a transmutatory Affection, it changes him that loves, into the very nature of that that he loves" (57-59). Later in the sermon Donne says that "the love of this pureness is part of this pureness it self, and no man hath it, except he love it" (582-83). To love, i.e. to court purity, is to become pure, but as in the Satyres, this goal must be achieved in this world. Donne rejects the "false affectation" and "hypocrical [sic] counterfeiting" of the Roman religion's way to purification, where "the soul is abstracted... not onely from passions, and perturbations, but from the ordinary way of coming to know any thing"- - that is, where the soul apart from the body of sense comes to an immediate, unmediated apprehension of God (95-96, 98-100). In contrast, says Donne, "Christ himself contented himself with the ordinary way; He was hungry, and a fig-tree presented it self to him upon the way, and he went to it to eat" (105-7). For Donne, the proper way to purity is through involvement in the world. It is the dialectical ascent of Cardinal Bembo, rather than the via negativa of St. John of the Cross.

The key is a love of purity. Those who take this love as their "ultimate term," the apex of all they desire, will find their desires and actions come into conformity with this guiding principle and, thus, become pure. The heart, the seat of desire, the seat of love, is itself variable and inscrutable, says Donne. It will, like the humourous courtier of Satyre I, latch upon any object that catches its fancy. It is like a piece of paper cast into a stream: "this paper is not addressed, as a ship, to a certain port, or upon any certain purpose, but expos'd to the disposition of the tyde, to the rage of the winde, to the wantonness of the Eddy, and to innumerable contingencies, till it 
wear out to nothing" (279-83). Similarly, says Donne, "if a man suffer his heart to issue upon any of these fluid and transitory things of this world, he shall have cor vafrum, \& inscrutabile, He shall not know where to finde his own heart" (284-86). "But," says Donne a few lines later, "if the heart can fix it self upon that which is fixt, the Almighty and immoveable God, if it can be content to inquire after it self, and take knowledge where it is, and in what way, it will finde the means of cleansing" (290-94). Donne's syntax here is awkward, but he seems to be saying that the heart must first fix itself upon God and then examine itself; and as in Satyre III, the heart should keep that knowledge that it comes upon, as it comes upon it along the way. Truth comes, then, as a cumulative effect, and this accumulation is a progress that is, as we will see, envisioned as a courtship upward.

The process of purification described here is similar to that of Satyre III. It involves an athletic pursuit of an object of desire balanced with careful consideration. This pursuit of purity is described as an ordeal that involves "studious ... endeavour" (89). Donne goes on to explain that in practical terms, this love of purity, this guiding principle or governing value, means " $[\mathrm{t}]$ hat we keep clean that heart by a continual diligence, and vigilancy over all our particular actions" (322-23) and, later in the sermon, by "preconsideration, and weighing your actions before hand" (495-96) — that is, by standing and enquiring right. And then Donne applies these ideas explicitly to executing one's vocation in the world: "consult with thine own Conscience in those little actions, which either their own nature, or the custom of the time, or thy course of life, thy calling, and the example of others in thy calling made thee think indifferent" (535-38). This process is described as an ascent up a hill in language that recalls Satyre III. Such a man as Donne describes

... shall ascend into the Hill of the Lord, he shall be admitted to all the benefits that the Christian Church can give him; but onely he that hath a pure heart, a care to glorifie God, in a holy watchfulness upon all his particular actions, to the exclusion of lesser sins, stabit, shall stand safe, confident, unshaken, in his holy place, even in the judgment of God; clean hands justifie him to men, a pure heart to God. (555-61)

Donne is not making one's choice of church a prerequisite of public life, as he does in Satyre III, but his choice of text does assume that church life is essential to public life. There will be more to say on this point later.

The effect of this pursuit of purification is a reordering of all values. Pureness of heart, says Donne, can only be "preserved...by this noble and incorruptible affection of Love, that puts a true value upon it, and therefore prefers it above all other things" (845-47). Donne says earlier, 
That that we drive to in all this, is this, that if we may not exceed in this love, which is natural, and commanded, much less in any other. So that there is nothing in this world left, for this noble and operative affection, Love, to work upon, but this pureness of heart. Love it therefore, that thou mayst seek it, love it that thou mayest have it; love it that thou mayest love it. (739-44)

This orientation governs all other desires. Drawing from the field of medicine, Donne notes that unlike other body parts, the heart is in perpetual motion and is therefore much more difficult to cure of its wounds. "Therefore," he continues, "when we lay such a weight upon the heart, as may settle it, fix it, give it a reposedness and acquiescence, though it do receive some wounds, though it be touched with some tentations, it may be cured" (789-92). Donne quickly turns this image to its metaphoric meaning:

But is there any such weight as should so settle the heart, the soul of Man? This love of Pureness is that weight. Amor est pondus anima; sicut gravitas, Corporis; As the weight of my body makes that steady, so this love of Pureness is the weight and the ballast of my soul; and this weight stays the palpitation, the variation, the deviation of the heart upon other objects; which variation frustrates all endeavours to cure it. (792-99)

This process is both purifying and inspiring, a goad to improvement. Not only is the love of pureness a weight, but "The love of this pureness is both the ballast and the frait, to carry thee steadily and richly too, through all storms and tempests, spiritual and temporal in this life, to the everlasting Jerusalem" (800-2). Earlier in the sermon Donne expresses this ascent of desire in different terms: "All love which is placed upon lower things, admits satiety; but this love of this pureness, always grows, always proceeds: It does not onely file off the rust of our hearts, in purging us of old habits, but proceeds to a daily polishing of the heart, in an exact watchfulness" (583-87).

However, the human condition is such that corruption always threatens to creep in. So Donne warns "that you proceed vigilantly in your several wayes, with a fore-knowledge, that there is every where coluber in via, A Snake in the way; in every way that you can take, in every course of life, in every calling, there is some of the seed of the old Serpent" (818-21). But God's word through the ministry of the church is a light, and "[i]f by the benefit of this light, you consider every step you make, weigh every action you undertake, this is that love of Pureness, that Pondus anima, the setling of the heart, that keeps it from evaporating upon transitory things, and settles it so, as that it becomes capable of that cure, which God, in his Church...exhibits to it" (830-35). The thing one must love above all things 
is purity, and this love (to paraphrase a line from "The Good Morrow") all love of other things controls.

Less than a year later (14 Dec 1617), in a sermon that is obviously courtly, Donne emphasizes the continuity of past and present careers in those who have been called into sacred ministry. ${ }^{36}$ Preaching to Queen Anne and her household at Denmark House, Donne takes as his text Proverbs 8:17, "I love them that love me, and they that seek me early shall find me." Although the sermon ultimately focuses on the nature and manner of the sensual love figured in the verse, Donne also makes frequent correlations between amorousness and ambition. The courtship imagery of his chosen text thus puts the sermon into a frame of reference that is similar to that of Satyre III. In fact, as he launched into the opening lines of his sermon, those who knew Donne's history might easily have made a connection between the poet of the Satyres (among Donne's most widely known poems at the time) and the preacher standing before them. $\mathrm{He}$ begins,

AS THE PROPHETS, and the other Secretaries of the holy Ghost in penning the books of Scriptures, do for the most part retain, and express in their writings some impressions, and some air of their former professions; those that had been bred in Courts and Cities, those that had been Shepheards and Heardsmen, those that had been Fishers, and so of the rest; ever inserting into their writings some phrases, some metaphors, some allusions, taken from that profession which they had exercised before; so that soul, that hath been transported upon any particular worldly pleasure, when it is intirely turn'd upon God, and the contemplation of his all-sufficiency and abundance, doth find in God fit subject, and just occasion to exercise the same affection piously, and religiously, which had before so sinfully transported, and possest it. (1:5.1-13)

In the same way, Donne the preacher retains some of the same habit of thought that he himself employed as the young satirist seeking his vocation. Here Donne is making the same point as in Satyre III: one's worldly pursuits become sanctified when they are ultimately oriented toward service to God. The result of this orientation is a purification of these same activities and interests and, more importantly, these same motives: what was previously done "sinfully" is now done "piously."

In the first partition of the sermon Donne exploits the motivational quality of sensual love (it is a "stupid inconsideration" to have no desire at all), but qualifies this desire as one that is properly directed beyond the creature to the Creator (it is a "sullen indifferency ... to love one thing no more than another"), so that earthly desires are completed and subsumed by a higher order of motives (203-315, cf 1:3.161-21). In the second partition Donne discusses the manner of this love- "to seek him early" 
(the second part of the verse), which is to seek him diligently. Toward the end of the sermon, the same message of courtship relates even more closely to the central image of Satyre III. Here Donne is speaking of the image found in the opening verses of Proverbs 8, of wisdom crying from the top of high places:

It is true, that Christ in the beginning of this chapter, shadow'd under the name of wisdom, when he discovers [i.e. reveals] where he may be found, speaks in the person of humane wisdom as well as divine, Doth not wisdome cry, and understanding utter her voice? where these two words, Wisdom and Understanding, signifie Sapientiam, and Prudentiam; That wisdom whose object is God, and that which concerns our conversation in this world ...

Similar to truth in Satyre III, wisdom speaks from a hill, and again there is a correspondence between the ways of God (Sapientiam) and the ways of the world (Prudentiam), the latter being subservient to and perfected in the former. Donne continues,

for Christ hath not taken so narrow a dwelling, as that he may be found but one way, or in one profession; for in all professions, in all stations, in all vocations, when all our actions in our severall courses are directed principally upon his glory, Christ is eminent, and may easily be found. To that purpose in this place, Christ, in the person of wisdom, offers himselfe to be found in the tops of high places, and in the gates of Cities; to shew that this Christ, and this wisdom which must save our Soules, is not confined to Cloysters and Monasteries, and speculative men only, but is also evidently and eminently to be found in the Courts of religious Princes, in the tops of high places, and in the Courts of Justice (in the gates of the City). (390-407)

Donne again envisions an answer to the problem of the cloistered and contemplative scholar of Satyre I, and again his answer is conceived as purification through a dialectic of courtship signified in the image of a hill, where worldly motives are reordered and perfected in relation to a higher order of values. Christ's wisdom baptizes worldly wisdom exercised in one's career. If one seeks ultimately Christ's wisdom, one's exercise of worldly wisdom will fall into line. And similar to Satyre III, there is a coincidence here between seeking religious truth and finding one's way in career.

This coincidence occurs again in an undated sermon on Psalm 32:8: "I will instruct thee, and teach thee in the way which thou shalt goe, I will guide thee with mine eye." Throughout the second partition of this sermon and into the third, Donne consistently uses journey imagery to elaborate the idea of being "in the way" (in via) rather than merely seeking the way. ${ }^{37}$ It is an important distinction. As in the Satyre III, Donne finds a solution 
in the continual process of pursuing an ultimate end rather than finding and settling on or even envisioning a satisfactory set of circumstances. Near the beginning of the second partition he applies the notion of God's direction to assert the possibility of constancy in one's profession: "he shall be able to walk in any profession, and to make good any station, and not be diverted by the power of any tentations incident to that calling" (9:16.421-23). Donne emphasizes the need to walk circumspectly and then raises Augustine's injunction that it is "via qua gradieris, \& non cui harebis, A way to walke in, not to sticke upon" and that one should not stall in the way or loiter (541-42). He warns against laziness and urges his congregation to continue in the way earnestly and with purpose, and he characterizes this pursuit as a journey up a hill where the ascent is continual: "A Christian hath no Solstice, no highest point, where he may stand still, and goe no farther" (561-62). It is our duty, says Donne, "in this way, humbly, and patiently, and laboriously to walke towards him, without stopping upon any thing in this world, either preferments on the right, or disgraces on the left hand" (574-76). Hill imagery is handled lightly and briefly here, but the same courtship paradigm is at work in the next partition in Donne's elaboration of the eye of God as a controlling principle in one's life, from the final phrase in his text: "I will guide thee with mine eye". The eye of God is a means of recovery when one stumbles in the way; the eye returns one to the path and directs the journey. The effect of this eye is first conversion, then union with God. Awareness of the gaze of God creates in the subject a self-consciousness about his or her actions. Donne asks, "Can any man give his body to uncleannesse, his tongue to prophanenesse, his heart to covetousnesse, and at the same time consider, that his pure, and his holy, and his bountifull God hath his eye upon him?" (663-66). And the self-conscious subject returns God's gaze: "If his eye be upon me, and mine upon him, (O blessed reflexion! O happy reciprocation! O powerfull correspondence!) Ipse evellet, He will plucke my feet out of the net, though I be almost ensnared, almost entangled, he will snatch me out of the fire, deliver me from the tentation" (674-79). To summarize in the language of courtship: God, at the apex, draws the subject to Himself and keeps each person in the way because of the self-consciousness God creates in him or her. This discussion of the subject's journey through life toward God is again cast in the context of church politics. Here Donne does not deliberate the various church forms available to his congregation as he does in Satyre III, but instead defends the English church against the exclusive claims of Rome. Donne does, however, use similar language in describing the church as "the Pillar of Truth" that, like the pillars of cloud and fire in the exodus, guides each congregant (442-78). The threats and 
challenges on the way come in the form of reproaches and defamation cast upon the English church, mostly by Papists but also by schismatics. In this sermon Donne again uses the language of courtship to talk about a reorientation of motives toward God as a means of purifying ambition, and again we find a coincidence of church politics and career.

The convergence of church politics and public career is significant in charting the relationship between the other four Satyres (which are concerned with public, secular careers) and Satyre III, which seems to be primarily a poem about religious affiliation: at least so it seems, until one considers the second image of the poem, the flower planted on the bank of the stream. This image makes it clear that the previous discussion about the politics of religion is part and parcel of finding a conscionable career path through the world of affairs:

\footnotetext{
That thou mayest rightly'obey power, her bounds know;

Those past, her nature,' and name is chang'd; to be

Then humble to her is idolatrie;

As streames are, Power is; those blest flowers that dwell

At the rough streames calme head, thrive and do well,

But having left their roots, and themselves given

To the streames tyrannous rage, alas are driven

Through mills, and rockes, and woods, and at last, almost

Consum'd in going, in the sea are lost:

So perish Soules, which more chuse mens unjust

Power from God claym'd, then God himselfe to trust. (100-10)
}

Richard Strier and Ronald Corthell both struggle with the apparent contradiction of this poem's two primary images of a dynamic seeker of truth on the one hand and a static dweller in truth on the other. In construing the radicalism of the poem, Strier sees in the flower imagery, especially the closing couplet, a strict and simple binary: one must trust either in God directly or in "mens unjust / Power." 38 According to Strier, Donne allows no possibility of relying on just men: all hierarchy is collapsed into binary and the athletic ascent in pursuit of truth is replaced with "dwelling" in the position of truth that is acquired by direct access to God. Corthell moderates Strier's point somewhat with the qualification that this is an imagined position of truth rather than an actual occupation of truth. Corthell resorts to sophisticated postmodern theory (Althusser) to explain the discrepancy between the closing image of an "ideal of harmonious and fixed relation to power" and the image of the particularized and localized circumstances of radical, liberal individualism in the hill. ${ }^{39}$

Thus we are left with a strange contradiction. Yet as Strier himself brilliantly shows, there is a symbolic connection between the activity of 
these two key symbols: the "thudding slowness and onomatopoetic structure" of "about must, and about must goe" (line 81) are echoed in the "mills, and rockes, and woods" (line 107) that characterize the movement through the rough stream. ${ }^{40}$ The poetics of the text seems to suggest a complementary relationship between these two images. Strier reconciles the images by subsuming the activity of seeking within a larger notion of Stoic stasis, of actively "dwelling" and "stand[ing and] inquiring right." ${ }^{11}$ I suggest it is the reverse, that the apparently static image of the flower assumes the dynamic of a courtship that is always aligning with and seeking an object of desire (truth, power) that is found in God (after all, line 107 echoes lines 81). Moreover, the second metaphor should not be expected to duplicate the dynamic of the first: one metaphor may not be able to do all the work of another or include all the possible associations made available by the other. In fact, these two metaphors emphasize two very different and contrary dynamics. The first pertains primarily to truth, the second to power. The first is concerned with the motion of the human subject struggling through the world of power toward truth; the second depicts the contrary movement of power-top-down from the source of power-and the plight of the individual caught within this flow. It is not so much the stationary quality of the flower that is at issue as its rootedness. The flower is dynamic in a different way, growing toward its source in its roots; it is dynamic not in its transportation, but in its assimilation of its source as it grows and flourishes outward in the world. Even with this shift in emphasis, the flower image does not preclude the dialectic of heavenly and earthly power in pursuit of truth, signified in the hill. The questing subject who keeps God as a point of reference will presumably find him/herself in line with just agents of power, for they will share the same ultimate source. This ultimate point of reference is the key to keeping all subjects, at whatever point in the hierarchy, in the way of justice and truth. What is figured here, then, is not quite a "direct and unmediated relation to the divine source," as Strier suggests. Rather, what we have in this image is a merging of the divine and the social orders so that the divine incorporates and controls the social. While in one sense, as Donne notes in Satyre V, the Queen, as the highest ranking person in the socio-political order, is the head of the stream from which all blessing and power flows, ultimately, as a picture of divine authority, this head is only the temporal, immediate source of authority, subsumed by a source that is much higher (and deeper).

The social order is a necessary element in human relations with divine power. The subject must, as the cloistered scholar learns, enter into the social network of power and activity. This is the immediate experience of truth and power, in the world. But this experience finds its proper point of 
reference beyond the social. One lives through the social but is always moving, about and about, to the divine. For practical reasons, one must choose a church, but this and every other temporal choice is provisional and tentative, subject ultimately to one's prior commitment to the source of all power. Here and in the hill image every temporal exigency is weighed, measured, and circumscribed with respect to an ultimate object of desire found in God, whether Church, truth, or honour. In the Satyres as a whole, each turn of plot, each encounter, each compromising circumstance has its answer in this central image, which symbolically reorients every occasion toward ultimate concerns. Motives are purified in a courtship athletically and continuously pursued as one doubts wisely and stands inquiring right, taking one's end in God as a point of reference. Donne's courtship topoi are not in themselves unique: as cultural commonplaces they are by definition common. What is unique in Donne is the persistence of this habit of thought from the beginning to the end of his literary career and his thorough use of these topoi and the intensity of his rhetorical deployment of them. In both the Satyres and the sermons Donne is singular in his full embrace of courtship, not to transfer (and thus eschew) but to translate worldly motives into a new and fuller truth in a courtship of the divine.

\section{Notes}

1. John Carey builds on R. C. Bald's characterization of Donne as an unprincipled and ambitious careerist: see Carey, John Donne: Life, Mind \& Art (New York: Oxford UP, 1981); and Bald, John Donne: A Life (Oxford: Clarendon, 1970). For a critique of Carey and a more balanced reading of the complexity of Donne's situation, see Annabel Patterson, "Misinterpretable Donne: The Testimony of the Letters," JDJ 1.1-2 (1982), pp. 39-53. See also her later works: "All Donne," in Soliciting Interpretation: Literary Theory and Seventeenth-Century English Poetry, eds. Elizabeth D. Harvey and Katharine Eisaman Maus (Chicago: U Chicago P, 1990), pp. 37-67; and "John Donne, Kingsman?," in The Mental World of the Jacobean Court, ed. Linda Levy Peck (Cambridge: Cambridge UP, 1991), pp. 251-72, where Patterson refutes and revises Bald, Carey and Goldberg's rendering of Donne's absolutist politics. See Jonathan Goldberg, James I and the Politics of Literature (Baltimore: Johns Hopkins UP, 1983), pp. 210-19. On the immediate audience of the Satyres see Arthur F. Marotti, John Donne, Coterie Poet (Madison: U Wisconsin P, 1986), pp. 34-39.

2. On Donne's causuistical turn of mind, see Camille Wells Slights, The Casuistical Tradition in Shakespeare, Donne, Herbert, and Milton (Princeton: Princeton UP, 1981), pp. 149-82; and "Participating Wisely in Satyre III," JDJ 10.1-2 (1991), pp. 91-95.

3. For studies in the narrative progression of the poems, see the following. Ronald J. Corthell focuses on autobiographical development, in "Style and Self in Donne's Satires," TSLL 24.2 (1982), pp. 156-57. Frank Kerins shows the development of the satirist's perspective, in "The 'Businesse' of Satire: John Donne and the Reformation 
of the Satirist," TSLL 26.1 (1984), pp. 37, 55. Emory Elliott suggests that the third poem provides the thematic focus of the set, in "The Narrative and Allusive Unity of Donne's Satyres," JEGP 75 (1976), p. 105. John R. Lauritsen finds a narrative progression from a detached presumption of superiority to self-discovery, in "Donne's Satyres: The Drama of Self-Discovery," SEL 16 (1976), pp. 119-21. M. Thomas Hester shows a progression of the satirist's struggle to find a decorous Christian voice and notes also the "mythic structure of the sequence" which charts the speaker's journey from innocence, through experience, to obedience, in Kinde Pitty and Brave Scorn: John Donne's Satyres (Durham: Duke UP, 1982), pp. 12-14.

4. Donne would later become "polluted," in the eyes of Sir Thomas Egerton and Sir George More, owing to his transgressive marriage to Anne More in 1601. Obversely, from Donne's point of view, his integrity was threatened when his own principled choice came into conflict with the seemingly capricious demands of public life. Louis A. Knafla's factual history of Donne's connection with Egerton in this period details Donne's anti-Catholic activities and manoeuvring for career, but says very little about his work in weeding out corruption in the courts: see "Mr Secretary Donne: The Years With Sir Thomas Egerton," in ed. David Colclough, John Donne's Professional Lives (Woodbridge: D. S. Brewer, 2003), pp. 37-71.

5. N. J. C. Andreasen describes it as a "soliloquy conducted in meditative isolation," in "Theme and Structure in Donne's Satyres," SEL 3 (1963), p. 69. Frank Kerins argues that "Satire III should be read as a 'dialogue of one,' an introspective analysis of the presuppositions from which spring both the secular and religious angles of vision" ("The 'Businesse' of Satire," p. 46). See also Hester, Kinde Pitty, p. 13.

6. I am indebted to Professors Gary Stringer and Ted-Larry Pebworth for this information. I would also like to thank my colleague Ron Cooley for reading this paper in its final stages and offering sage advice.

7. Thomas V. Moore, "Donne's Use of Uncertainty as a Vital Force in Satyre III," MP 67 (1969), p. 43.

8. Richard C. Newton, "Donne the Satirist," TSLL 16.3 (1974), p. 435.

9. Slights, "Participating Wisely," p. 93.

10. Clothing here signifies both corruption and inconstancy. See William B. Hunter, "Difficulties in the Interpretation of John Donne's Satyre I," The South Central Bulletin 43.4 (Winter 1983), p. 110. For the theme of "inconstancy," see Sister M. Geraldine Thompson, "Donne's Notitia: The Evidence of the Satires," UTQ 36 (1966), p. 26. James S. Baumlin observes that clothing is a reflection of one's spiritual state, in John Donne and the Rhetorics of Renaissance Discourse (Columbia: U Missouri P, 1991), pp. 69-70, 88. See also Rosemary Boston, "The Variable Heart in Donne's Sermons," Christian Scholars Review 2 (1971), pp. 36-41.

11. All references to the sermons are to The Sermons of John Donne, eds. and intro. George R. Potter and Evelyn M. Simpson, 10 vols. (Berkeley: U of California P, 1953-1962), 3:1.155-92; 3:10.467-70, 518-39; 6:1.474-77; 6:3.391-92; 9:12.3-9.

12. R. C. Bald notes this conflict between the active and contemplative life in Donne but sees Donne as taking a traditional Stoic approach to the problem. See Bald, pp. $122-23$.

13. Ronald J. Corthell, “'Coscus onely breeds my just offence': A Note on Donne's 'Satire II' and the Inns of Court," JDJ 6.1 (1987), p. 26. 
14. Nancy Mason Bradbury, "Speaker and Structure in Donne's Satyre IV," SEL 25 (1985), pp. 87-107; Dennis Flynn, "Donne's Most Daring Satyre: 'richly For service paid, authoriz'd', 'JDJ 20 (2001), pp. 115-19.

15. Corthell, “A Note on Donne's 'Satire II',” pp. 29-30.

16. Paul R. Sellin argues that Donne's hill of truth very closely resembles details of a golden medallion commemorating the Synod of Dort (May 1619), one of which Donne received on his Doncaster mission: "The Proper Dating of John Donne's 'Satyre III'," HLQ 43 (1980), pp. 282ff. W. Milgate offers a good survey of supposed sources, in Milgate ed., John Donne: The Satires, Epigrams, and Verse Letters (Oxford: Clarendon, 1967), pp. 290-92, 306ff. M. Thomas Hester catalogues a few more and adds a couple of his own in "John Donne's 'Hill of Truth'," ELN 14 (1976), pp. 100-105.

17. Hester, "John Donne's 'Hill of Truth'”, pp. 100-105.

18. Hester cites Plato's Timaeus as a source for the idea of the spiral motion of the soul (1976, pp. 102-103). Socrates' allegory of the horses and chariot in Plato's Phaedrus is another possible intellectual source behind Donne's combination of ascent, desire, orientation, and purification (248A-E, 253C). The Celestial Hierarchies of [Pseudo] Dionysius the Areopagite (whom Donne cites in the sermons) is another excellent model of how a hierarchical order of being lends itself to notions of purification.

19. Dennis Flynn, John Donne and the Ancient Catholic Nobility (Bloomington: Indiana UP, 1995). Walton asserts that Donne traveled to Spain and Italy after the Cadiz and Azores expeditions, but R. C. Bald refutes this chronology, given known events of Donne's life in these years, and he suggests instead that Donne's trip to the continent might have occurred between 1589 and 1591 (pp. 50-51). Flynn, with sounder reason, speculates that Donne might have accompanied William Stanley in his travels to Spain and Italy between 1585 and 1588 (pp. 133-34; 170-71). Although Ascent of Mount Carmel, the written form of these ideas of the ascent of perfection, appeared posthumously in print in 1618, the text in manuscript, and even more so the teaching on which the text is based, circulated widely in Spain from the late 1570s onward; St. John of the Cross frequently used and distributed similar (though less detailed) diagrams in his program of instruction. (See E. Allison Peers, trans. and ed. from the critical edition of P. Silverio De Santa Teresa, The Complete Works of Saint John of the Cross, rev. ed., vol. 1 [London: Burns, Oates \& Washbourne Ltd., 1953], pp. xxxi-xxxiii.) Donne, a young Catholic travelling in Spain in the early 1590s, could easily have encountered these teachings.

20. Harry J. Brown, “'Soul's Language Understood': John Donne and the Spanish Mystics," $Q / W / E / R / T / Y 11$ (2001), p. 27.

21. Brown, p. 28.

22. Brown, p. 30, quoting McGinn.

23. Kenneth Burke's notion of courtship is elaborated in A Rhetoric of Motives (Berkeley: $\mathrm{U}$ of California P, 1969). For a fuller treatment of this courtship topos in Donne see my forthcoming book Holy Ambition: Rhetoric, Courtship, and Devotion in the Sermons of John Donne (Tempe, AZ: Medieval and Renaissance Texts and Studies).

24. See Burke, pp. 221-33.

25. References to Donne's poems are to John Shawcross's edition, The Complete Poetry of John Donne (Garden City, NY: Anchor Books, 1967).

26. See Mary Claire Randolph, “The Structural Design of the Formal Verse Satire," $P Q$ 21 (1942), p. 373. 
27. On the subject of self-implication cf. 7:16.567-72; and on the generic analogy of satire and sermon cf. 5:16.574-89.

28. Thomas O. Sloan analyzes Satyre III as a classical oration but stops short of relating it to the sermon, even though the rhetorical structure and dynamic are almost identical, in "The Persona as Rhetor: An Interpretation of Donne's Satyre III," The Quarterly Journal of Speech 51 (1965), pp. 14-27. Hester finds in contemporary sermons a model of "Christian Zeal" in the tradition of Biblical prophets, which Donne brings to the Satyres to complement the classical elements of satire (Kinde Pitty, 7-11). James S. Baumlin notes Donne's dissatisfaction with the Juvenalian and Horatian modes of the first two Satyres and his search for a more amenable voice in Persius, which lends a more homiletic fashion to the third and fifth poems: Baumlin, "Donne's Christian Diatribes: Persius and the Rhetorical Persona of 'Satyre III' and 'Satyre V'," in The Eagle and the Dove: Reassessing John Donne, eds. Claude J. Summers and Ted-Larry Pebworth (Columbia, MO: U of Missouri P, 1986), pp. 92, 102. See also: Sister M. Geraldine Thompson, "Donne's Notitia," p. 27; and Elliott, "The Narrative and Allusive Unity," p. 108; Mary Claire Randolph, p. 373; Arnold Stein, "Voices of the Satirist: John Donne," in English Satire and the Satiric Tradition, ed. Claude Rawson (Oxford: Blackwell, 1984), pp. 86-89; and Joshua Scodel, "John Donne and the Religious Politics of the Mean," in John Donne's Religious Imagination: Essays in Honor of John T. Shawcross, eds. Raymond-Jean Frontain and Frances M. Malpezzi (Conway, AR: UCA, 1995), pp. 61-67.

29. Maria Salenius discusses Donne's use of metaphor as a means of reforming meaning attached to Romanish practices in order to transform and purify them, in "True Purification: Donne's Art of Rhetoric in Two Candlemas Sermons," in John Donne and the Protestant Reformation: New Perspectives, ed. Mary Arshagouni Papazian (Detroit: Wayne State UP, 2003), pp. 314-34.

30. See Bald and Goldberg for views on Donne's search for a career. Goldberg very briefly discusses the present sermon to argue Donne's absolutist politics and absolute surrender to political authority in his search for a career, and completely misses the subtlety of Donne's handling of this subject-king relationship (Goldberg, p. 213).

31. Those present included "the archbishop of Caunterburie, the Lord Keeper, Lord Privie-seale, the earle of Arundell, the earle of Southampton, the Lord Hayes, the controller, Secretarie Winwod, the Master of the Rolles, with divers other great men" who, according to Chamberlain (29 Mar 1617), heard Donne deliver a "daintie" sermon that was generally well liked (Sermons, Vol. 1, p.125).

32. M. L. Donnelly, “'To furder or represse': Donne's Calling," JDJ 8.1\&2 (1989), pp. 115-24. Donnelly explicates the sermon on Proverbs 22:11-a model for Donne's use of religious discourse of calling that he applies similarly in patronage poems to rationalize his social ambitions.

33. Donnelly, "Donne's Calling," p.108.

34. M. L. Donnelly, "Saving the King's Friend and Redeeming Appearances: Dr Donne Constructs a Scriptural Model for Patronage." The Yearbook of English Studies 21 (1991), pp. 107-20.

35. Donnelly, "Saving the King's Friend," p.115.

36. Peter McCullough takes a different tack, describing the sermon as "an extended condemnation of church papistry addressed directly to Anne herself," in "Preaching to a Court Papist?: Donne's Sermon Before Queen Anne, December 1617," JDJ 14 (1995), p. 70. 
37. For journey imagery in the sermons see: Winfried Schleiner, The Imagery of John Donne's Sermons (Providence: Brown UP, 1970), pp. 85-93; Gale H. Carrithers Jr., Donne at Sermons: A Christian Existential World (Albany: State University of New York P, 1972), pp. 90-98. Carrithers and James D. Hardy Jr. refer to the journey topos in talking about the integration of two aspects of calling in the Christian's life: ambassadorship (a heavenly calling) and the daily tasks of life on earth (including career), in “'Not upon a Lecture, but upon a Sermon': Devotional Dynamics of the Donnean Fisher of Men,"in John Donne and the Protestant Reformation: New Perspectives, ed. Mary Arshagouni Papazian (Detroit: Wayne State UP, 2003), pp. 335-59, esp. 339-46.

38. Richard Strier, "Radical Donne: 'Satire III'," ELH 60 (1993), p. 312.

39. Ronald Corthell, Ideology and Desire in Renaissance Poetry: The Subject of Donne (Detroit: Wayne State UP, 1997), p. 46.

40. Strier, p. 311.

41. Strier, p. 310. 